\title{
AVALIAÇÃo de ÁREAS DE PRESERVAÇÃo PERMANENTE EM SUPERFíCIE PLANIMÉTRICA E SUPERFÍCIE MODELADA NA ÁREA DE PROTEÇÃO AMBIENTAL DA REGIÃO SERRANA DE PETRÓPOLIS - RJ
}

\section{EVALUATION OF PERMANENT PRESERVE AREAS ON PLANIMETRIC SURFACE AND MODELED SURFACE IN ENVIRONMENTAL PROTECTION AREA OF PETRÓPOLIS MOUTAIN REGION - RJ}

\author{
Fernando de Souza Antunes ${ }^{1}$, Pedro Henrique Ferreira Coura ${ }^{1}$, Manoel do Couto Fernandes ${ }^{1}$ \\ ${ }^{1}$ Universidade Federal do Rio de Janeiro (UFRJ), Rio de Janeiro, RJ, Brasil
}

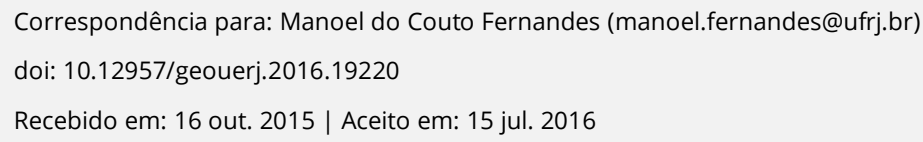

\section{RESUMO}

Áreas de Preservação Permanente (APP), estabelecidas pela legislação ambiental brasileira, tem diferentes e importantes funções para o ambiente e o ecossistema, incluindo: preservação dos recursos hídricos, da paisagem, da estabilidade geológica, da biodiversidade, dos fluxos gênicos de fauna e flora, a proteção do solo da floresta e garantia de bem-estar para a população humana. A delimitação cartográfica dessas áreas permite uma melhor a tomada de decisão, ajudando a resolver os conflitos existentes, detectando áreas prioritárias para a implementação de projetos destinados a reabilitar áreas degradadas. Portanto, o objetivo deste trabalho é avaliar um mapa de Áreas de Preservação Permanente contidas na Área de Proteção Ambiental da Região Serrana de Petrópolis (APA Petrópolis). Desta forma, os usuários serão capazes de analisar o atual estado das Áreas de Preservação Permanente e da relação que eles possuem com os usos conflitantes destes espaços. As Áreas de Preservação Permanente foram delimitadas usando Sistemas de Informação Geográfica (SIG) como uma ferramenta para operacionalizar e usar Modelos Digitais de Elevação (MDE) para aperfeiçoar a metodologia de delimitação destas áreas. As áreas como cursos d'água, nascentes, encostas com declividade superior a 45 graus, e lagos e reservatórios são alguns exemplos de áreas de preservação que foram mapeados, de acordo com a legislação ambiental brasileira. Sobrepondo um mapa de cobertura da terra, é possível observar um elevado nível de ocupação espacial, como mostrado na sobreposição das áreas já mapeadas e nas ortofotos de Instituto Brasileiro de Geografia e Estatística.

Palavras-chave: MDE, geoprocessamento, legislação ambiental, Área de Preservação Permanente, Área de Proteção Ambiental

\section{ABSTRACT}

Permanent Preservation Areas (PPA), established by Brazilian environmental law, have different and important functions for the environment and ecosystem, including: preservation of water resources, landscape, geological stability, biodiversity, and healthy flows of flora and fauna, the protection of the forest floor and the guarantee of welfare for the human population. The cartographic delimitation of these areas provides for better decision-making, helping to resolve existing conflicts by detecting priority areas for the implementation of projects designed to rehabilitate degraded areas. As such, the aim of this paper is to evaluate a Permanent Preservation Areas map within the Environmental Protection Area of Petrópolis Moutain Region (APA Petrópolis). Thus, users will be able to analyze the current state of Permanent Preservation Areas and the relationship they have with the conflicting uses of those spaces. Boundaries for the Permanent Preservation Areas was delimited using Geographic Information Systems (GIS) as a tool to operationalize and use Digital Elevation Models (DEM) to refine the methodology for delimiting boundaries for these areas. The areas with long water courses, springs, hillsides with slopes greater than 45 degrees, and lakes and reservoirs are some examples of preservation areas that have already been mapped according to Brazilian environmental legislation. Overlaying a land cover map, is possible to observe a high level of spatial occupation as shown in the overlapping of areas already mapped and in the orthophotos of the Brazilian Geographic and Statistical Institute.

Keywords: DEM, geoprocessing, environmental legislation, permanent preservation area, environmental protection area. 


\section{INTRODUÇÃO}

As Áreas de Preservação Permanente (APP) tem extrema importância ambiental e, portanto, é de grande importância conhecer suas localizações, ou seja, mapeá-las, para que se saiba o nível de preservação das mesmas.

O mapeamento de APP torna-se complicado, na medida em que a legislação apresenta várias interpretações para métodos e parâmetros a serem seguidos, tornando o mapeamento passível de subjetividade, fazendo com que haja diferentes delimitações de APP. Além disso, o correto mapeamento das APP é de extrema importância na tomada de decisões no que diz respeito à resolução de conflitos existentes entre a ocupação desordenada e manutenção das funções ambientais.

A proteção delas é de fundamental importância para o entendimento geoecológico da paisagem, pois estas influenciam no comportamento dos ecossistemas e podem servir como áreas prioritárias para a proposição de projetos de recuperação das funções ambientais das paisagens degradadas. Desta forma, ao pensar em estratégias para preservação e recuperação, fica clara a necessidade de realizar 0 mapeamento e a identificação das APP.

Outro problema relacionado ao mapeamento, segundo a legislação vigente, é que existe uma grande diferença entre o mapeamento feito a partir da carta topográfica, ou seja, superfície planimétrica (SP) e o mapeamento feito em superfície modelada (SM), levando em consideração a rugosidade do terreno (figura 1). Estes dois tipos de mapeamentos geram diferenças no perímetro e área das APP, diferenças estas que podem acarretar em conflitos de uso da terra. Estes conflitos podem ser agravados, por conta da deficiente fiscalização, mas também pela falta de material cartográfico dessas áreas, dificultando ainda mais o mapeamento das APP. 


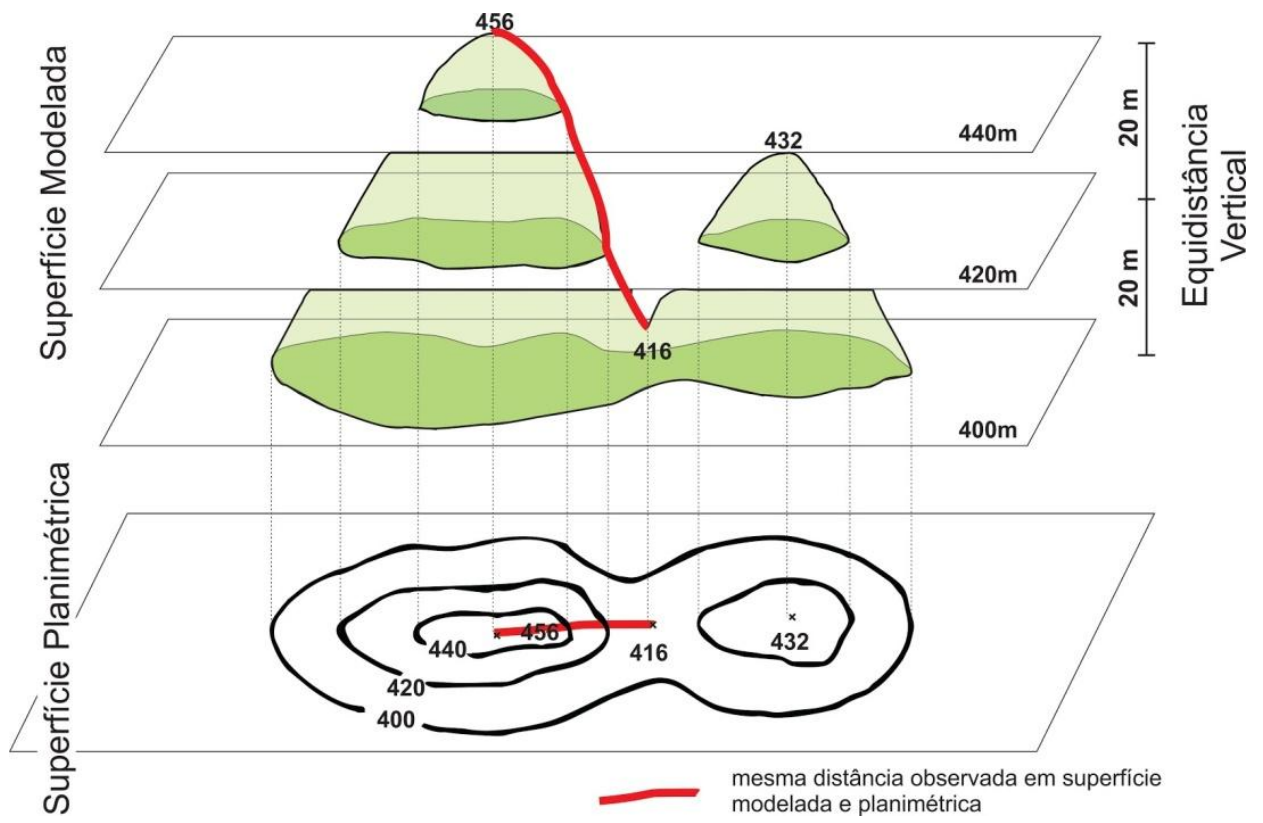

Figura 1. Representação de uma mesma distância em superfície planimétrica (SP), através de curvas de nível em cartas topográficas, e em superfície modelada (SM). Fonte: Adaptado de Menezes \& Fernandes (2013)

Neste contexto, torna-se importante apresentar uma avaliação da diferença de área em superfície modelada e superfície planimétrica das APP, em ambiente computacional, procurando avaliar as diferentes leituras e interpretações geradas pelas duas formas de mapeamentos que se pode elaborar, facilitando com isso a padronização do mapeamento de APP, tanto em campo quanto na base cartográfica. Este quadro apresentado forma o objetivo do trabalho, que foi avaliado para a APA Petrópolis, a qual possui uma série de características que fomentam este tipo de análise e são apresentados em seguida.

\section{ÁREA DE ESTUDO}

Este trabalho concentrou-se na Área de Preservação Ambiental da Região Serrana de Petrópolis (APA Petrópolis). A APA Petrópolis foi criada em 1982, sendo esta a primeira APA Federal do Brasil. Foi oficializada como APA Federal em 1992, sendo atualmente administrada pelo Instituto Chico Mendes de Biodiversidade (ICMBio) e tem a função de:

garantir a preservação dos remanescentes da Mata Atlântica, pertencente à Reserva da Biosfera da UNESCO, patrimônio nacional e da humanidade, o uso sustentável dos recursos naturais e a conservação do conjunto paisagístico da região (Pagani, 2003 apud Coura, 2012).. 
Segundo o Plano de Manejo da APA Petrópolis do IBAMA/MMA (2007) a APA Petrópolis ocupa parte dos municípios de Petrópolis (68,32\%), Magé (16,75\%), Guapimirim (10,39\%) e Duque de Caxias (4,54\%) estendendo-se por uma área de aproximadamente 595,22 km² (Figura 2). Além disso, abrange uma população aproximada de 300 mil habitantes e possui a biodiversidade ameaçada com os fortes impactos da alta densidade populacional, especialmente no vale do rio Piabanha, onde se localiza a cidade de Petrópolis.

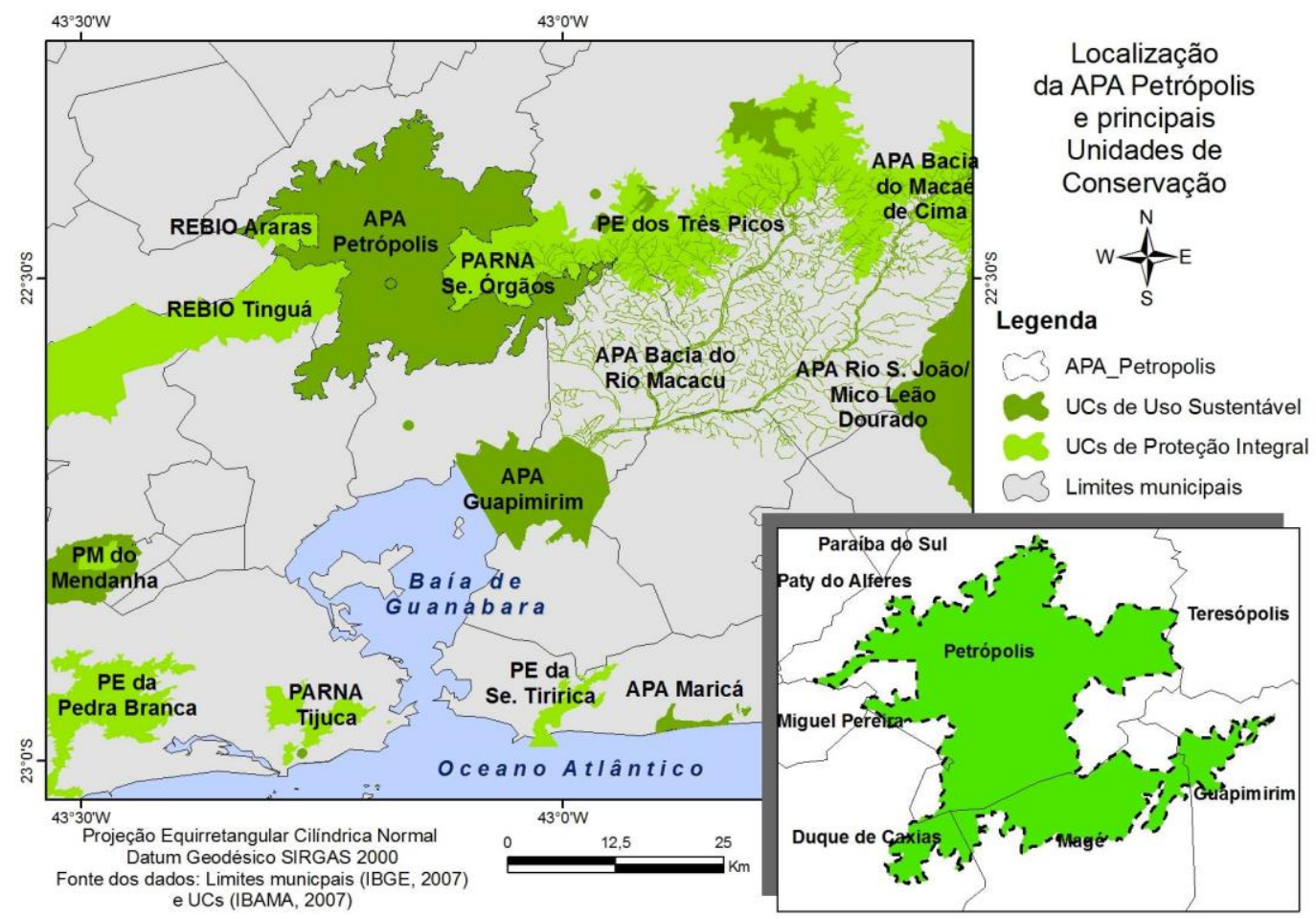

Figura 2. Localização da área de estudo. Fonte: Miceli (2011).

De acordo com IBAMA/MMA (2007), a APA Petrópolis, assim como as demais Unidades de Conservação (UC) da sua categoria, tem sua definição dada pelo Artigo $15^{0}$ do SNUC (Sistema Nacional de Unidades de Conservação da Natureza), que dá as diretrizes necessárias para a proteção e gestão das APA, como,

(...) uma área em geral extensa, com um certo grau de ocupação humana, dotada de atributos abióticos, bióticos, estéticos ou culturais especialmente importantes para a qualidade de vida e o bem-estar das populações humanas, e tem como objetivos básicos proteger a diversidade biológica, disciplinar o processo de ocupação e assegurar a sustentabilidade do uso dos recursos naturais $(\ldots)$. 
O mapeamento das APP da APA Petrópolis se faz necessário para uma melhor gestão dos diferentes conflitos existentes nessa UC. Segundo o Plano de Manejo da APA Petrópolis (IBAMA/MMA, 2007), esses conflitos são, em sua maioria, em função da ocupação humana nas APP, especulação imobiliária, resultando na degradação fluvial, exploração mineral (pedreiras) e exploração de produtos da fauna e flora.

Um ponto importante em relação à escolha da APA Petrópolis como área de estudo, é a sua topografia. Seu relevo acidentado é favorável para realização de avaliações em superfície modelada de mapeamentos realizados em superfície planimétrica. Além disso, na APA Petrópolis existem diversas áreas declivosas em que a população construiu casas de forma irregular (Figuras 3, 4 e 5).

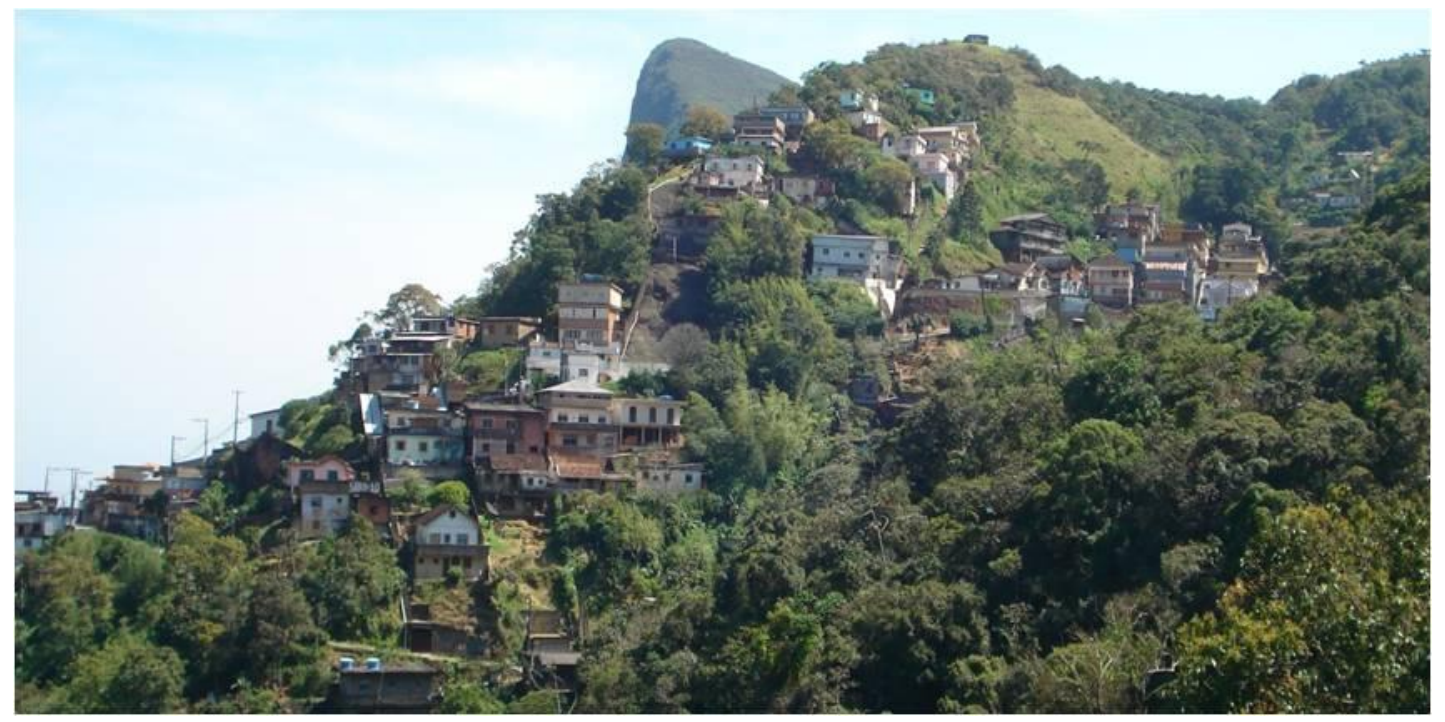

Figura 3. Construções em área declivosa na localidade Alto Independência. 


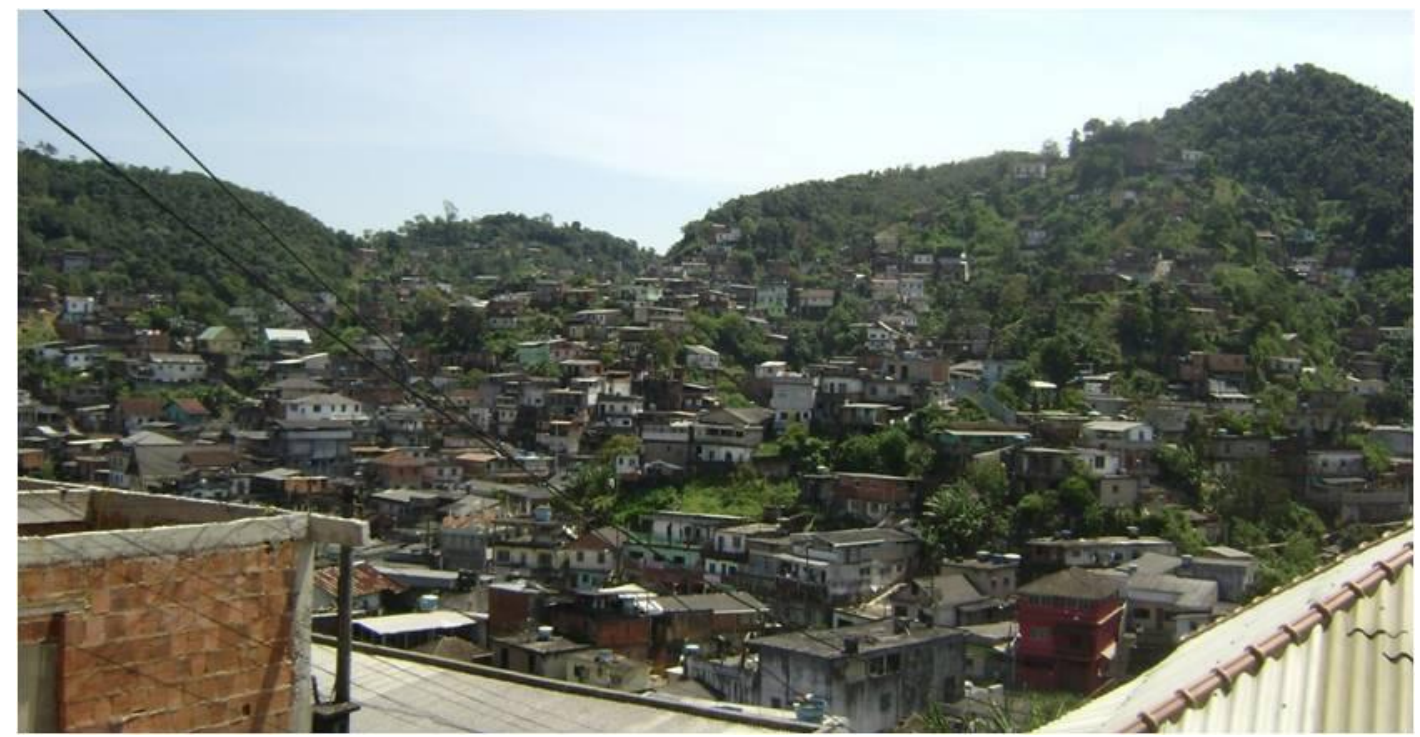

Figura 4. Construções em áreas declivosas na localidade Alto da Serra.

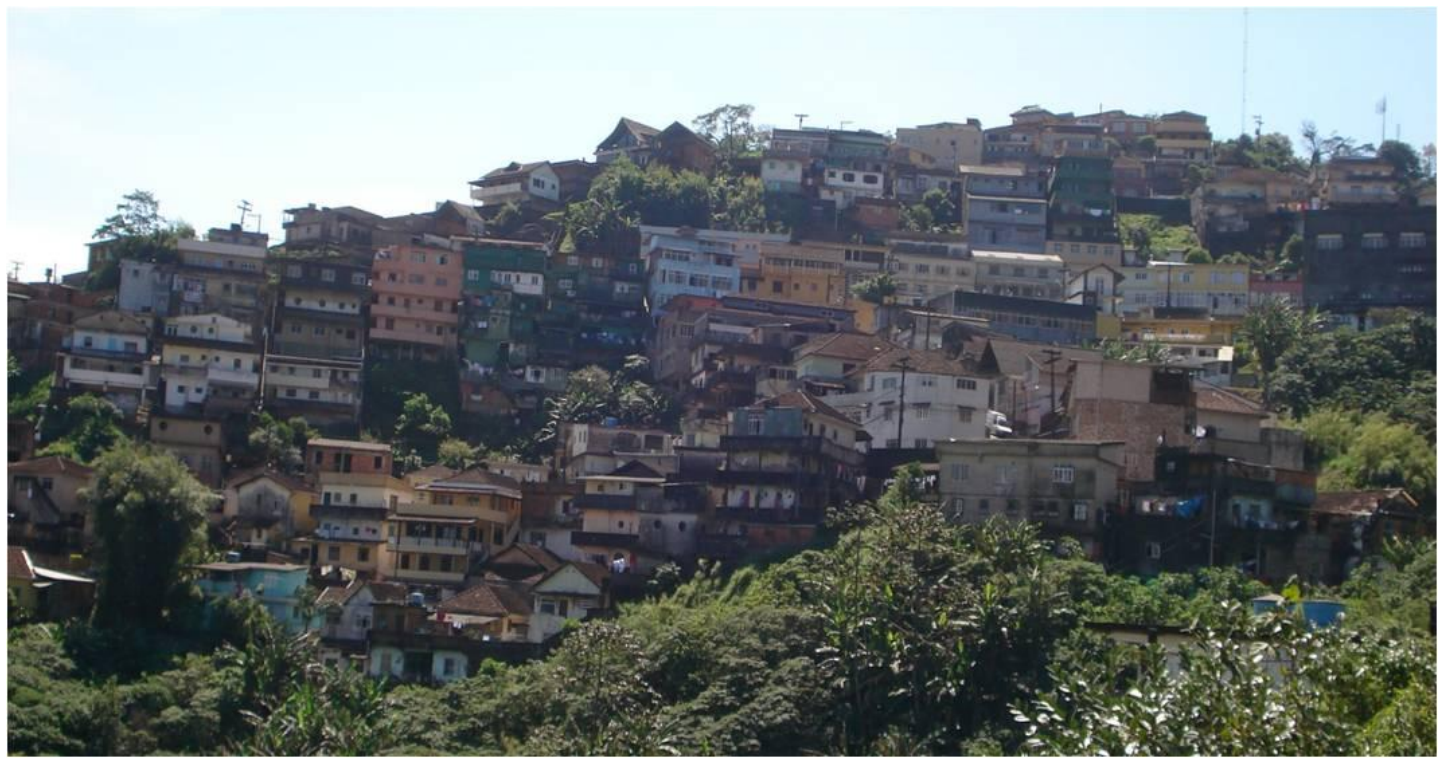

Figura 5. Construções em topo de morro na localidade Alto da Serra.

A APA Petrópolis está na Reserva da Biosfera da Mata Atlântica (RBMA), e conforme descrito no Plano de Manejo da APA (IBAMA/MMA, 2007), a RBMA possui cerca de $350.000 \mathrm{~km}^{2}$ de extensão, em forma de um grande corredor ecológico envolvendo até 15 estados brasileiros, incorporando diversas áreas-núcleo (representadas por UC), sendo este mais um ponto importante na escolha da área de estudo.

\section{DISCUSSÃO CONCEITUAL}


O presente trabalho possui dois elementos que dão sustentação conceitual e operacional ao objetivo central. Esses dois elementos são as Áreas de Preservação Permanente (APP) da APA Petrópolis, que se delineia como o objeto de estudo, e o Modelo Digital de Elevação (MDE), que é a geotecnologia chave para o desenvolvimento da proposta de análise em superfície modelada. Neste sentido, é apresentado a seguir uma discussão sobre estes dois elementos.

\section{Área de Preservação Permanente}

As APP têm sido preocupação do Estado há décadas, onde em 1934 já havia legislação que as normatizava, mesmo que de forma incipiente.

O $\operatorname{artigo~}^{4^{0}}$ do Decreto $\mathrm{n}^{0}$ 23.793/34 regia as chamadas, na época, de florestas protetoras, o que pode ser entendido atualmente como APP, como salienta COURA (2012). 0 artigo prevê que

\footnotetext{
(...) Serão consideradas florestas protetoras as que, por sua localização, servirem conjunta ou separadamente para quaisquer dos fins seguintes: a. Conservar o regime das águas; b. Evitar a erosão das terras pela ação dos agentes naturais; c. Fixar dunas; d. Auxiliar a defesa das fronteiras, de modo julgado necessário pelas autoridades militares; e. Assegurar condições de salubridade pública; f. Proteger sítios que por sua beleza mereçam ser conservados; g. Asilar espécimes raros da fauna indígena. (...).
}

As APP são áreas protegidas pela Lei Federal nº 4.771, de 15 de setembro de 1965 , bem como pelo novo Código Florestal, Lei nº 12.651, de 25 de maio de 2012 e a resolução CONAMA nº 303, de 20 de março de 2002, onde estas têm funções de grande importância para o meio ambiente e o ecossistema em que vivemos, dentre elas: preservação dos recursos hídricos, a paisagem, a estabilidade geológica, a biodiversidade, e os fluxos gênicos de flora e fauna, bem como a manutenção do bem estar da população humana (BRASIL, 2002).

Este trabalho se baseia na Resolução CONAMA nº 303/2002, que determina os parâmetros das APP avaliadas neste trabalho (quadro 1). Vale ressaltar que, em 2012 foi sancionada a Lei no 12.651 que 
cria o Novo Código Florestal Brasileiro, que de acordo com o Art. 1ํ “(..) estabelece normas gerais sobre a proteção da vegetação, áreas de preservação permanente e as áreas de reserva legal (...)" (BRASIL, 2012). O Novo Código Florestal mantem os mesmos parâmetros e critérios em relação as APP, no entanto, a maneira como a delimitação dessas áreas deve ser realizada não está prevista pelo Código Florestal, ficando a cargo do fiscal em campo realizar tal delimitação.

APP 1: Ao redor de nascentes ou olho d'água, ainda que intermitente, com raio mínimo de 50 metros de tal forma que proteja, em cada caso, a bacia hidrográfica contribuinte;

APP 2: Ao redor de lagos e lagoas naturais, em faixa de metragem mínima de:

- 30 metros, para os que estejam situados em áreas urbanas consolidadas;

- 100 metros para os que estejam situados em áreas rurais, exceto os corpos d'água com até 20 hectares de superfície, cuja faixa marginal será de 50 metros;

APP 3: Ao longo de rios ou qualquer curso d'água, em faixa marginal, medida a partir do nível mais alto, em projeção horizontal, com largura mínima de:

- 30 metros para os cursos d'água de menos de 10 metros de largura;

- 50 metros para os cursos d'água que tenham de 10 a 50 metros de largura;

- 100 metros para os cursos d'água que tenham de 50 a 200 metros de largura;

- 200 metros para os cursos d'água que tenham de 200 a 600 metros de largura;

- 500 metros para os cursos d'água que tenham largura superior a 600 metros;

APP 4: Em altitude superior a 1.800 metros, ou em Estados que não tenham tais elevações, à critério do órgão ambiental competente;

APP 5: Em encosta ou parte desta, com declividade superior a cem por cento ou quarenta e cinco graus na linha de maior declive;

Quadro 1. APP mapeadas. Adaptado de Coura (2012).

Existem algumas APP, como dunas, restingas e mangues que não serão contempladas neste trabalho por não estarem presentes na APA Petrópolis. Outras, como topo de morro, linhas de cumeada, locais de refúgio ou reprodução de aves migratórias também não foram contempladas na avaliação. 


\section{Modelo Digital de Elevação}

O Modelo Digital de Elevação (MDE) é a geotecnologia principal aplicada a este trabalho, pois a análise em superfície modelada é feita com base neste modelo, possibilitando, portanto, as comparações das entre áreas em superfície modelada e superfície planimétrica.

O conceito de superfície modelada vem sendo usada constantemente na pesquisa acadêmica, com destaque para Fernandes (2004), Fernandes \& Menezes (2005), Menezes \& Fernandes (2013), dentre outros. Neste trabalho a superfície modelada é assumida como a representação tridimensional do relevo, ou seja, modelo da superfície terrestre, levando em consideração sua altitude e declividade.

Existem diferentes conceitos relacionados à MDE. Como as análises realizadas são apenas utilizando as informações do relevo, será adotada a nomenclatura MDE (Modelo Digital de Elevação), tendo como base o trabalho de Felgueiras (1997), Felgueiras \& Câmara (1999), e Toutin (2006). Toutin (2006) define MDE como a modelagem do relevo não incluindo vegetação, construções, entre outros elementos situados acima da superfície terrestre. Caso esses elementos sejam levados em consideração os modelos assumem outras características e passam a ser chamados de Modelo Digital de Superfície. Abaixo, a figura 6 mostra a diferença entre os dois modelos.

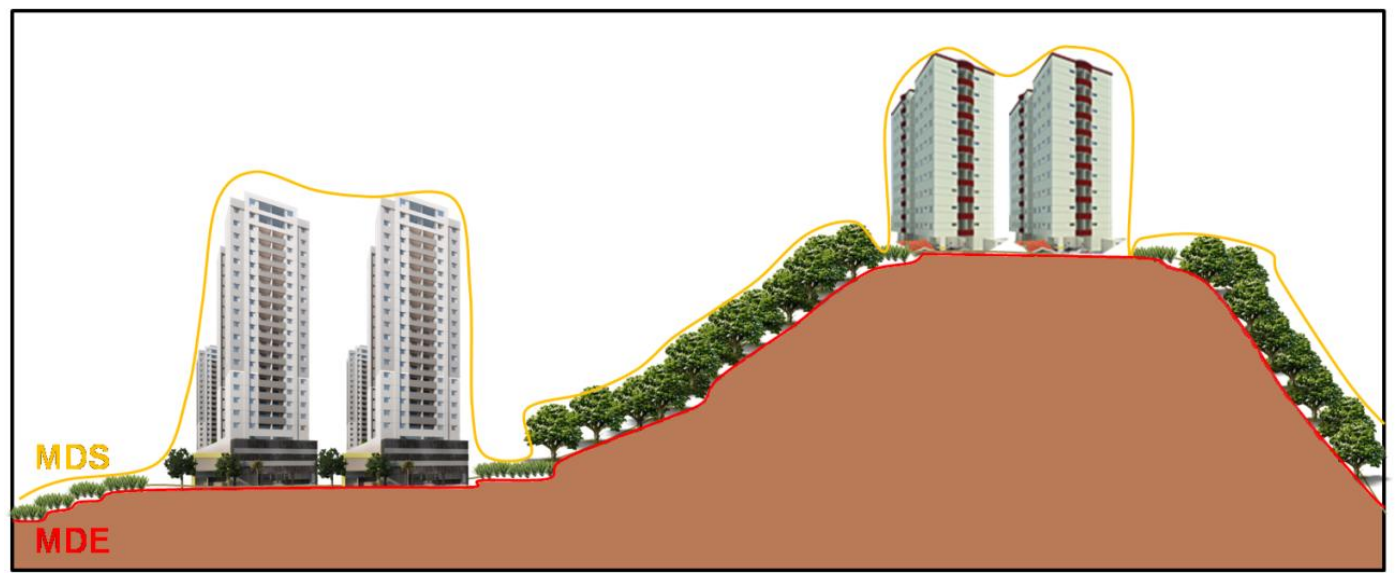

Figura 6. Esquema ilustrativo da concepção do Modelo Digital de Elevação (MDE) e Modelo Digital de Superfície (MDS). (COURA, 2012) 
Fernandes (2004) aborda a importância de se trabalhar com MDE, pois estes representam um esquema que busca de maneira material ou simbólica, criar um modelo simplificado de um recorte do mundo, baseando-se numa abstração da realidade. Desta forma, segundo o autor, estes modelos permitem uma visão mais próxima da realidade como a percebemos, possibilitando a construção de modelos mais ajustados à paisagem de análise.

Para este trabalho, foi utilizado um MDE baseado em rede irregular triangular (Triangular Irregular Network - TIN) e no algoritmo de ajuste linear. É adotado neste trabalho a sigla TIN, que é consagrada no meio científico para referência deste modelo (figura 7). Uma característica importante destes modelos é que leva em consideração a hidrografia na sua construção, ou seja, possibilitam a representação tridimensional da superfície através de modelos hidrologicamente consistentes, que também são conhecidos como Modelo Digital de Elevação Hidrologicamente Consistente (MDEHC).

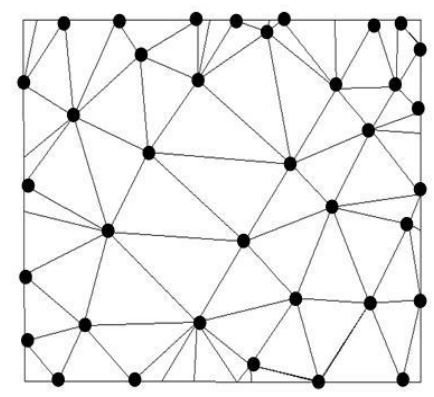

\section{- Amostras}

Figura 7. Rede Irregular Triangular (TIN). Fonte: Fernandes (2004)

\section{MATERIAIS E MÉTODOS}

O trabalho desenvolvido foi dividido em cinco grandes etapas: dados de entrada, produtos derivados, delimitação (mapeamento) em superfície planimétrica, quantificação das APP mapeadas em superfície modelada e análise dos resultados (figura 8). 


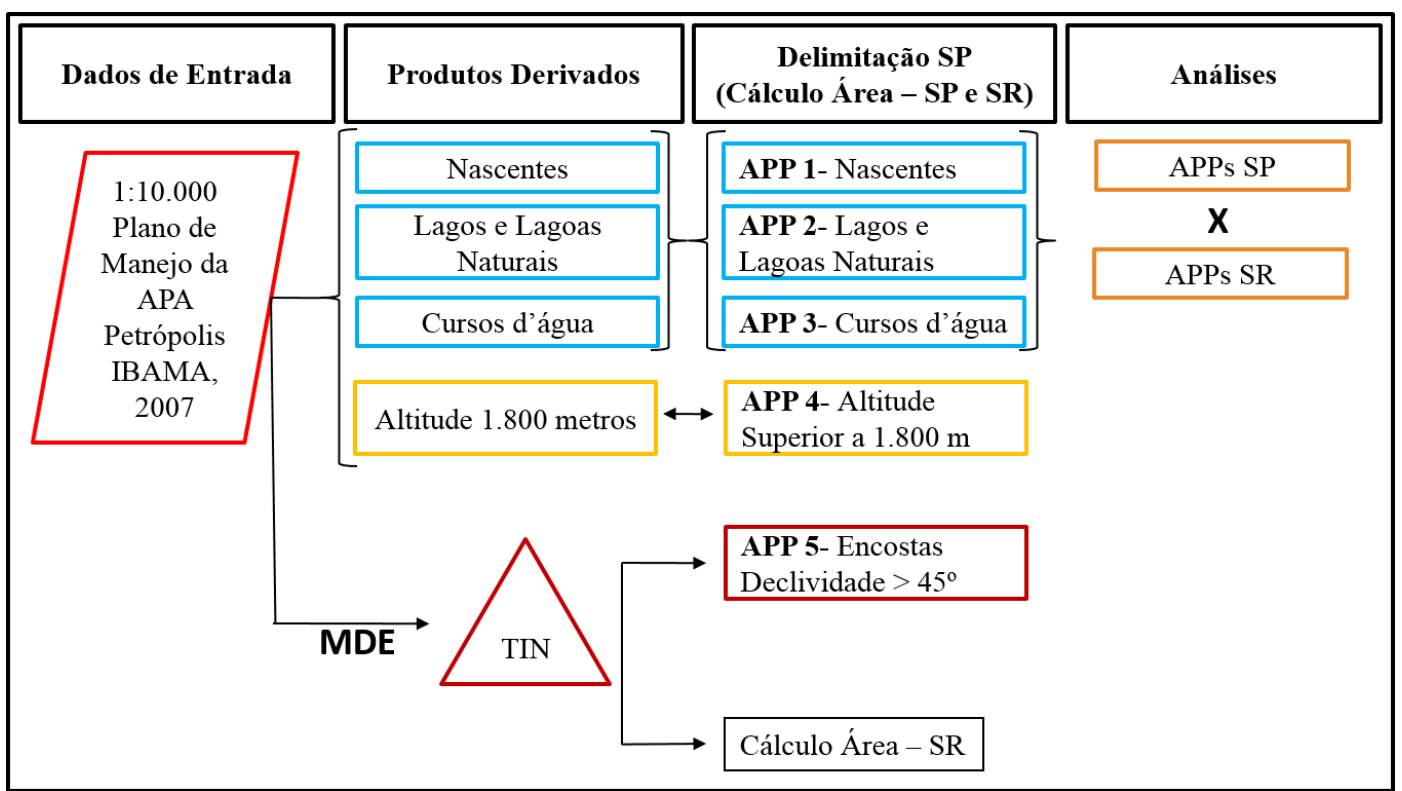

Figura 8. Fluxograma de operacionalização do trabalho, demonstrando cada etapa a ser realizada

Inicialmente foi feita a edição da base cartográfica proveniente do Plano de Manejo da APA Petrópolis (IBAMA, 2007), que foi confeccionada a partir de informações planialtimétricas das cartas topográficas da Fundação CIDE/RJ de 1998, pela Prefeitura Municipal de Petrópolis/PROSPEC de 1999, e da FUNDREM de 1978, todas na escala 1:10.000 (figura 9).

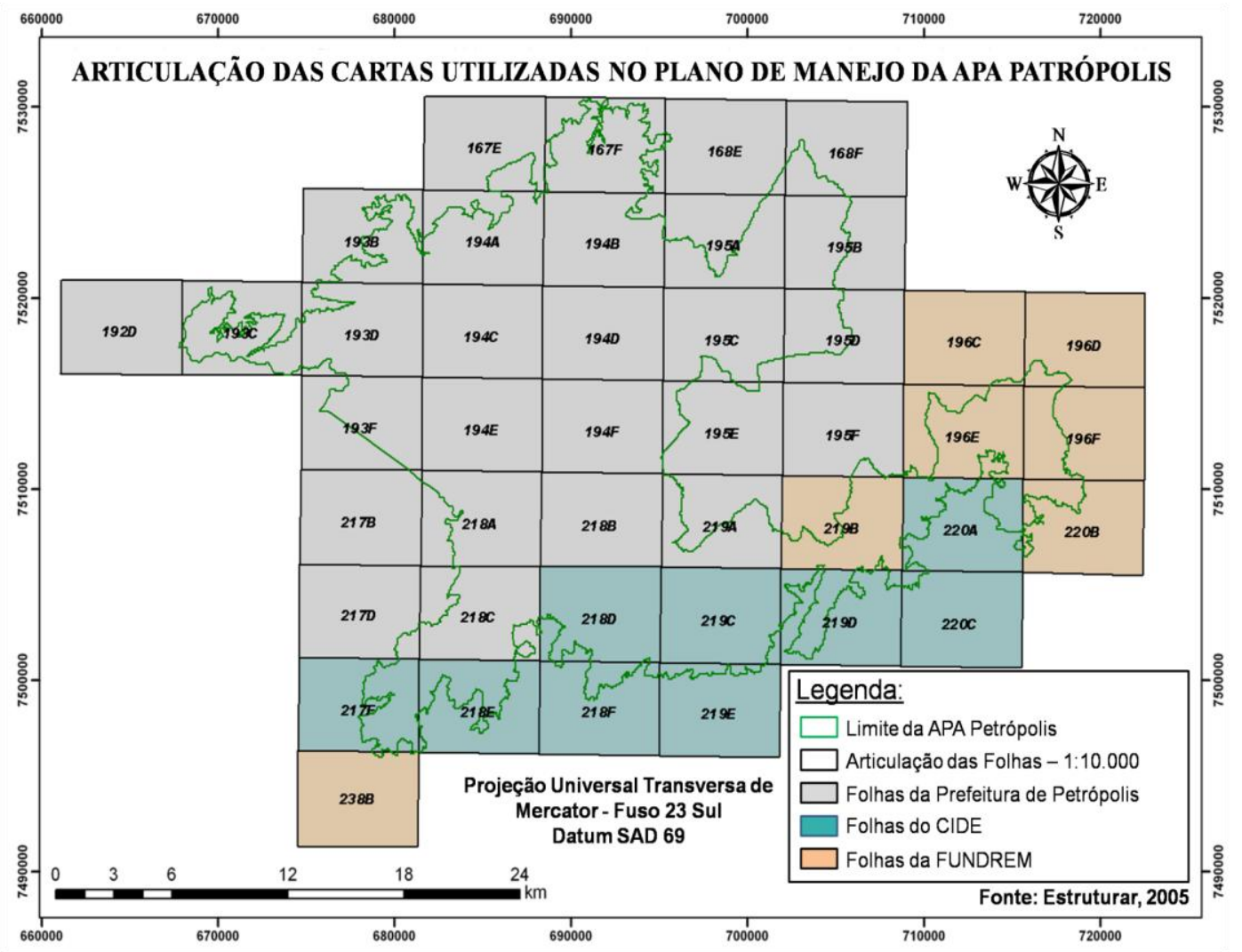

Figura 9. Articulação das cartas utilizadas no Plano de Manejo - APA Petrópolis. Fonte: Adaptado de ESTRUTURAR (2005). 
Esta base cartográfica possuía algumas inconsistências e foi preciso passar por um processo de edição para corrigir tais erros, como: curvas de nível cruzadas ou incompletas, segmentos de hidrografia incompletos e/ou com a orientação do fluxo do rio incorreto (jusante à montante, onde o correto é de montante à jusante) (figuras 10a e 10b).
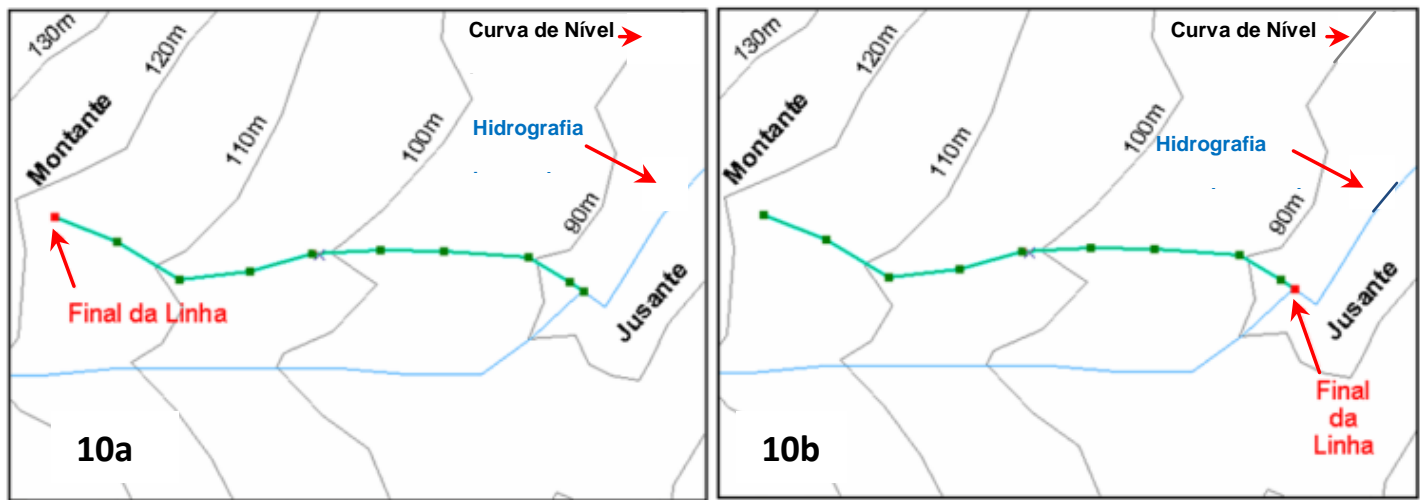

Figura 10a e 10b. Exemplos de inconsistências da base cartográfica (10a) e edições executadas (10b).

Depois do tratamento inicial dos dados usados para o mapeamento das APP, foi iniciado à extração de informações da base cartográfica relativas aos cursos d'água, lagos, lagoas, reservatórios e curva de nível de 1.800 metros.

Para a APP de altitudes maiores que 1.800 metros, foram utilizadas as curvas de nível de 1.800 metros para limitar e foi considerado toda a área acima dessas curvas como APP.

Em relação às APP de cursos d'água, a resolução CONAMA n 303/02 diz que a área de preservação variará de acordo com a largura do rio, onde para os rios que tem sua largura inferior a 10 metros, a área de influência para cada margem foi de 30 metros; já para os rios que tem largura entre 10 e 50 metros, a área de influência para cada margem foi de 50 metros. De acordo com o Manual Técnico de Convenções Cartográficas do Ministério da Defesa (BRASIL, 1998), sendo a escala de trabalho 1:10.000, os rios que tem largura de até 8 metros, são representados no mapa por uma linha simples, enquanto que os rios que tem largura superior à 8 metros são representados por duas linhas, indicando, desta forma, as margens do rio. 
Com o intuito de obedecer ao texto da lei, todos os rios de margem simples foram enquadrados como rios com largura inferior a 10 metros, e os de margem dupla passaram por uma mensuração de sua largura para que pudesse ser feita a separação dos trechos dos rios e fosse aplicada a área de influência correta, identificando os menores e maiores que 10 metros (figura 11). É importante ressaltar que na área de estudo não foram encontradas larguras superiores a 50 metros, limitando as classes das APP de cursos d'água apenas as menores que 10 metros e entre 10 e 50 metros.

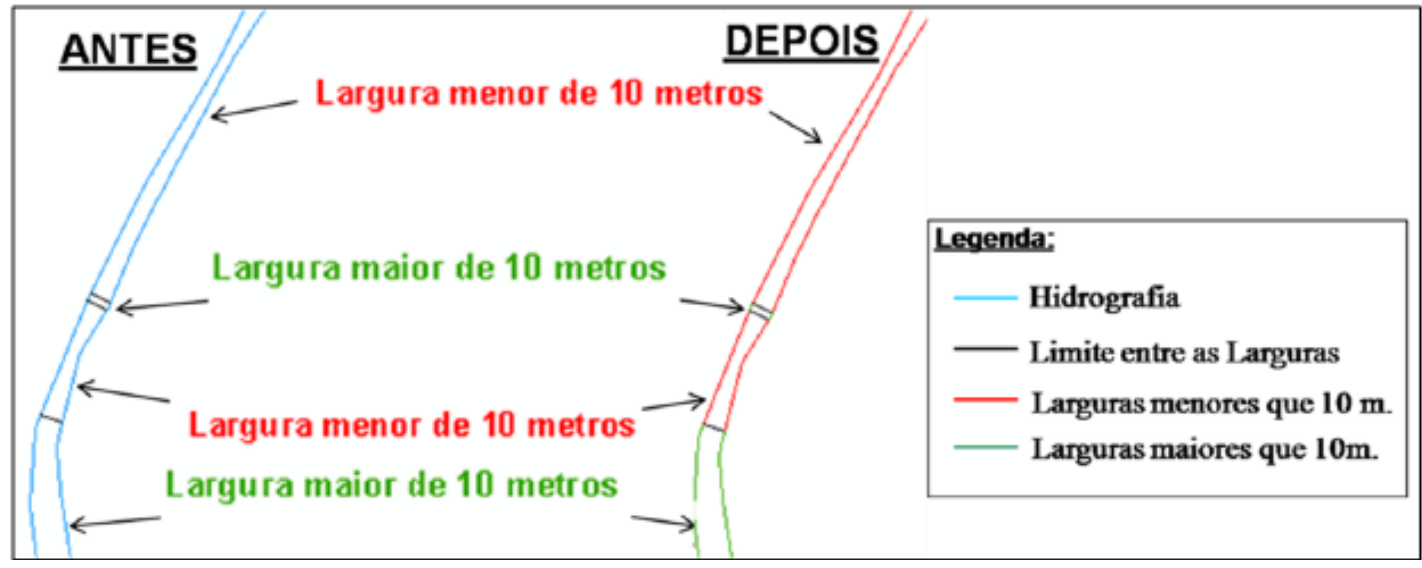

Figura 11. Medições realizadas para separação dos trechos de hidrografia.

A APP de nascente foi mapeada utilizando a ferramenta Buffer, onde o SIG cria uma área de influência em torno do ponto que foi considerado como nascente. Neste trabalho, a nascente corresponde a todos os pontos no início dos canais de primeira ordem. Essa diretriz foi adotada devido à falta de informações mais detalhadas acerca da localização das nascentes. Sabe-se que as nascentes podem migrar de uma posição para outra, de acordo com uma série de fatores, como a época do ano e regime de chuvas (figura 12a). A resolução CONAMA nº 303/2002 aponta que para lagos, lagoas e reservatórios, a área de influência é de 50 metros na área urbana e 100 metros na área rural (figura $12 b)$.
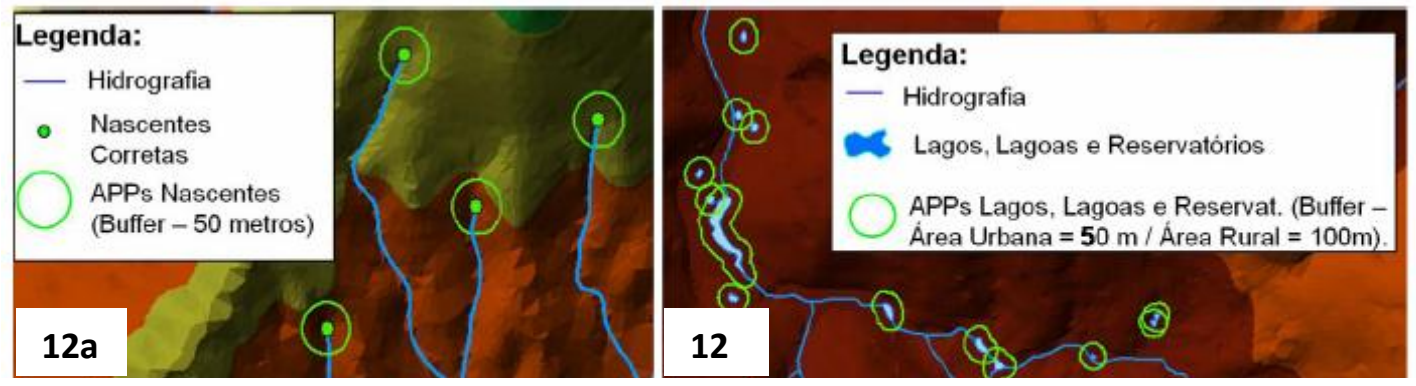

Figura 12a e 12b. Demonstração do mapeamento em superfície planimétrica das APP de nascentes (12a) e das APP de lagos, lagoas e reservatórios (12b). 
Para que fosse mapeada a APP de declividades superiores à $45^{\circ}$, foi feito um MDE TIN (Triangular Irregular Network). A geração deste modelo é importante para a realização das diferenças de áreas das APP em superfície planimétrica e superfície modelada.

Para a geração do modelo TIN, foram utilizados como elementos de entrada as curvas de nível, a hidrografia, lagos, lagoas e reservatórios, os pontos cotados e a área de delimitação da APA Petrópolis da base cartográfica descrita anteriormente, no software ArcGIS® 9.3 e o seu interpolador de ajuste linear com a triangulação de Delaunay com restrições. Segundo Fernandes (2004), este modelo se comporta melhor em áreas de grande declividade, como é o caso da APA Petrópolis.

Inicialmente o modelo foi gerado com elementos cortados para o exato limite da APA, mas depois de alguns testes realizados principalmente no limite da APA, foi decidido gerar outro modelo com informações não somente de dentro da APA, mas também com informações de fora, ou seja, foi realizado um buffer de 200 metros do limite da APA que serviu como área de limite para incorporação das feições a serem na geração do modelo. A diferença de altitude encontrada pelos testes realizados nas bordas dos dois modelos pode ser vista como exemplo na figura a seguir, onde essa diferença se dá a partir do momento que, com uma maior quantidade de informação de fora da APA, a interpolação fica mais detalhada, o que resulta em um valor de altitude mais próximo da realidade no limite da APA (figura 13).

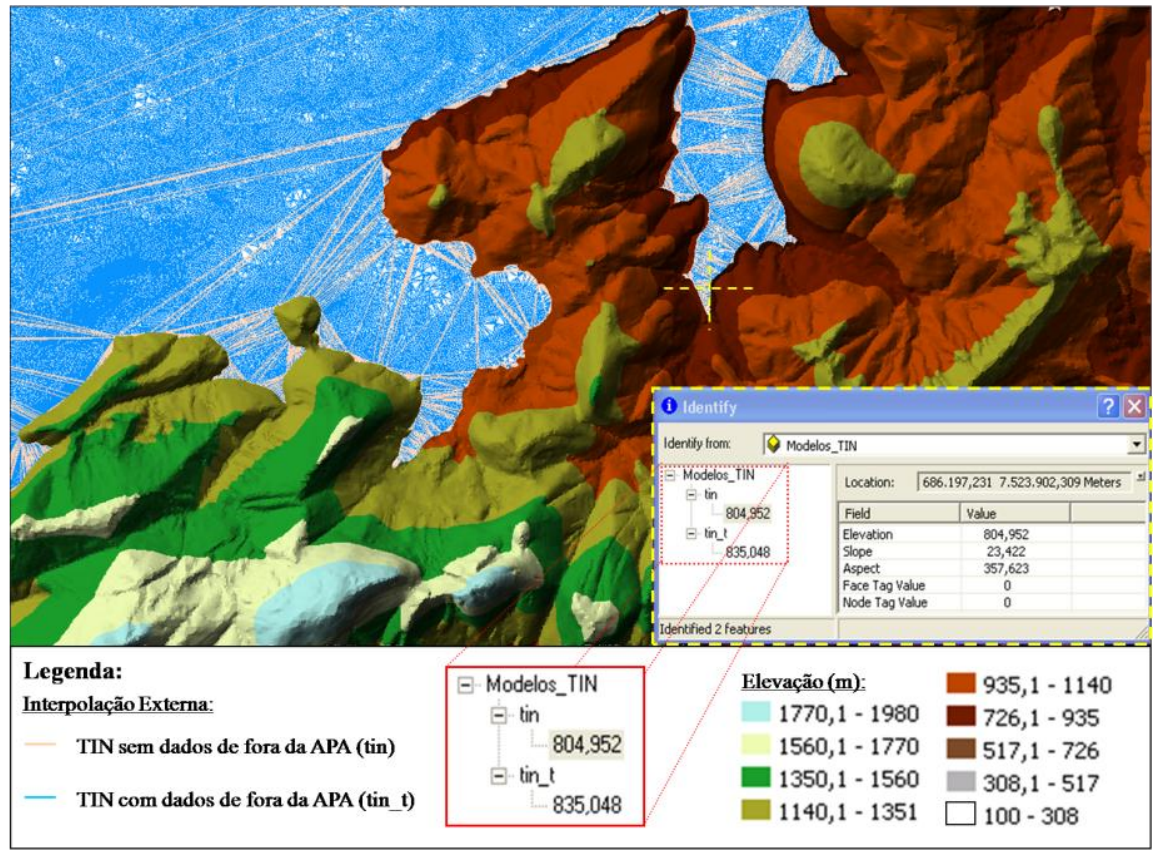


Figura 13. Comparação realizada entre os MDE TIN gerados sem (tin) e com (tin_t) informações do entorno da APA.

A figura 14 mostra o MDE de grade triangular irregular (TIN) elaborado, que utilizou informações do entorno da APA.

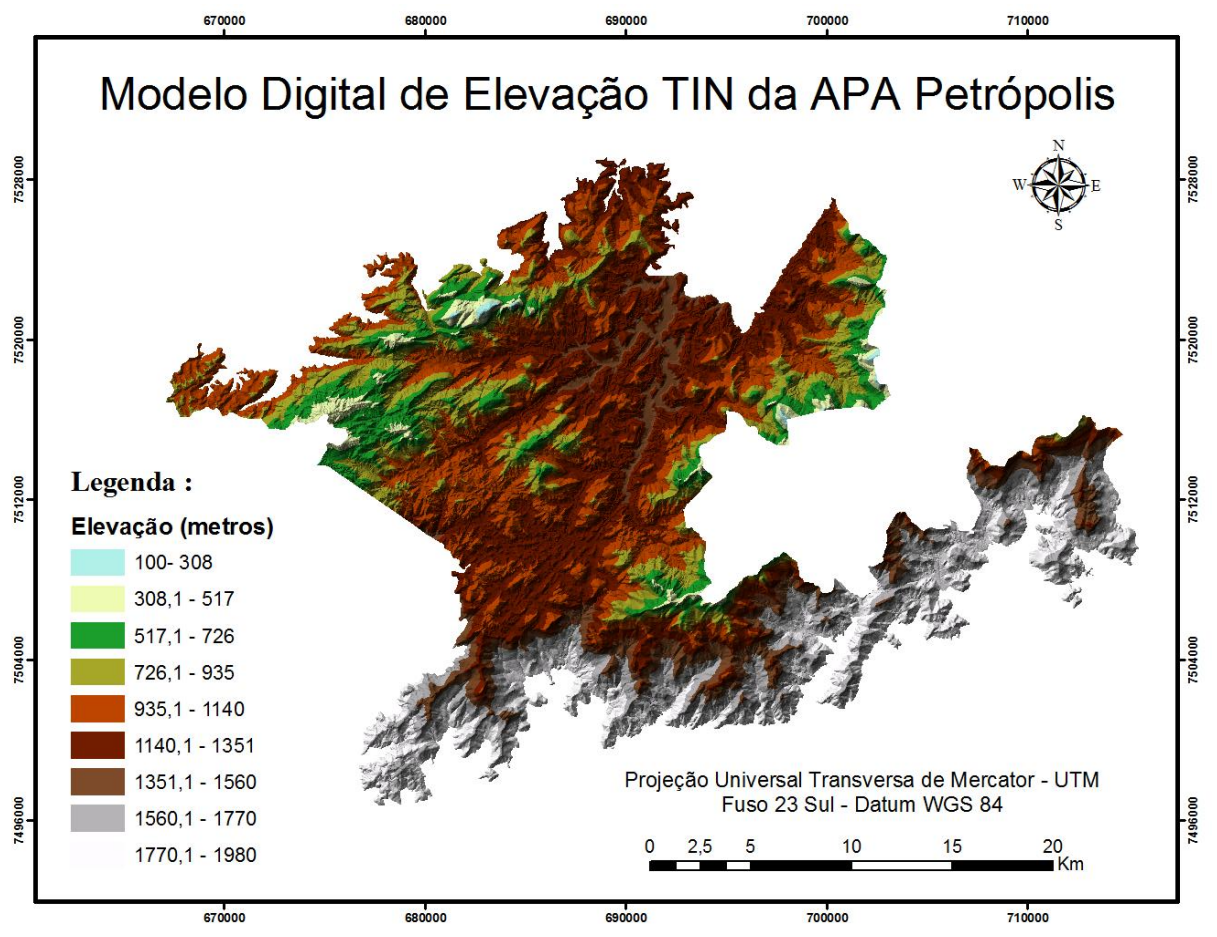

Figura 14. Modelo Digital de Elevação TIN da APA Petrópolis.

Uma vez gerado o MDE, foi feito um mapa de forma de encostas e a partir deste mapa foi possível fazer uma classificação e separação das encostas com declividade superior a 45ํำ (figura 15).

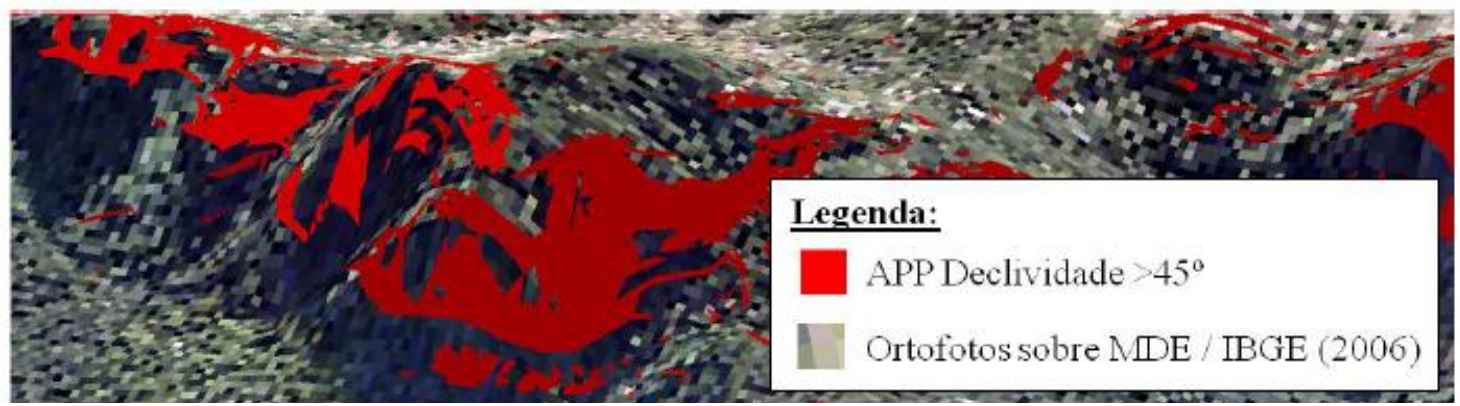

Figura 15. Demonstração do mapeamento da APP de encostas com declividade superior a $45^{\circ}$. 
Uma vez que essas delimitações estivessem prontas, passou-se então às análises dos dados gerados com os mapeamentos. Estas análises foram feitas comparando a área em superfície planimétrica e superfície modelada.

\section{RESULTADOS E DISCUSSÕES}

Para avaliar o comportamento das Áreas de Preservação Permanente contidas na Área de Proteção Ambiental da Região Serrana de Petrópolis (APA Petrópolis) em superfície planimétrica e modelada foi tomado como base o cálculo das APP e da própria APA Petrópolis nas referidas superfícies.

Inicialmente foi feita uma análise da área total da APA Petrópolis em superfície planimétrica e superfície modelada. Em superfície planimétrica, a APA Petrópolis possui 596,07 km² de área e em superfície modelada a APA Petrópolis possui $694,53 \mathrm{~km}^{2}$, portanto, uma diferença de 16,52\%. Esse comportamento de aumento no valor de área é refletido em todas as outras análises propostas e corrobora com os dados apresentados por Fernandes et al. (2012) e Miceli et al. (2015) ao fazer este tipo de análise para índices geomorfológicos no maciço da Tijuca (RJ) e dinâmica do uso e cobertura da terra na APA Petrópolis, respectivamente.

Em um segundo momento esta análise foi realizada para a área total de APP, em superfície planimétrica e superfície modelada. Novamente o comportamento de aumento da área em superfície modelada foi identificado. A área total das APP em superfície planimétrica foi calculada em 117,66 $\mathrm{km}^{2}$ e em superfície modelada apresentou um incremento de $31,76 \%$, ou seja, em valores absolutos passou para $155,04 \mathrm{~km}^{2}$ (figura 16). 
Cálculo de área das APP em SP e SM

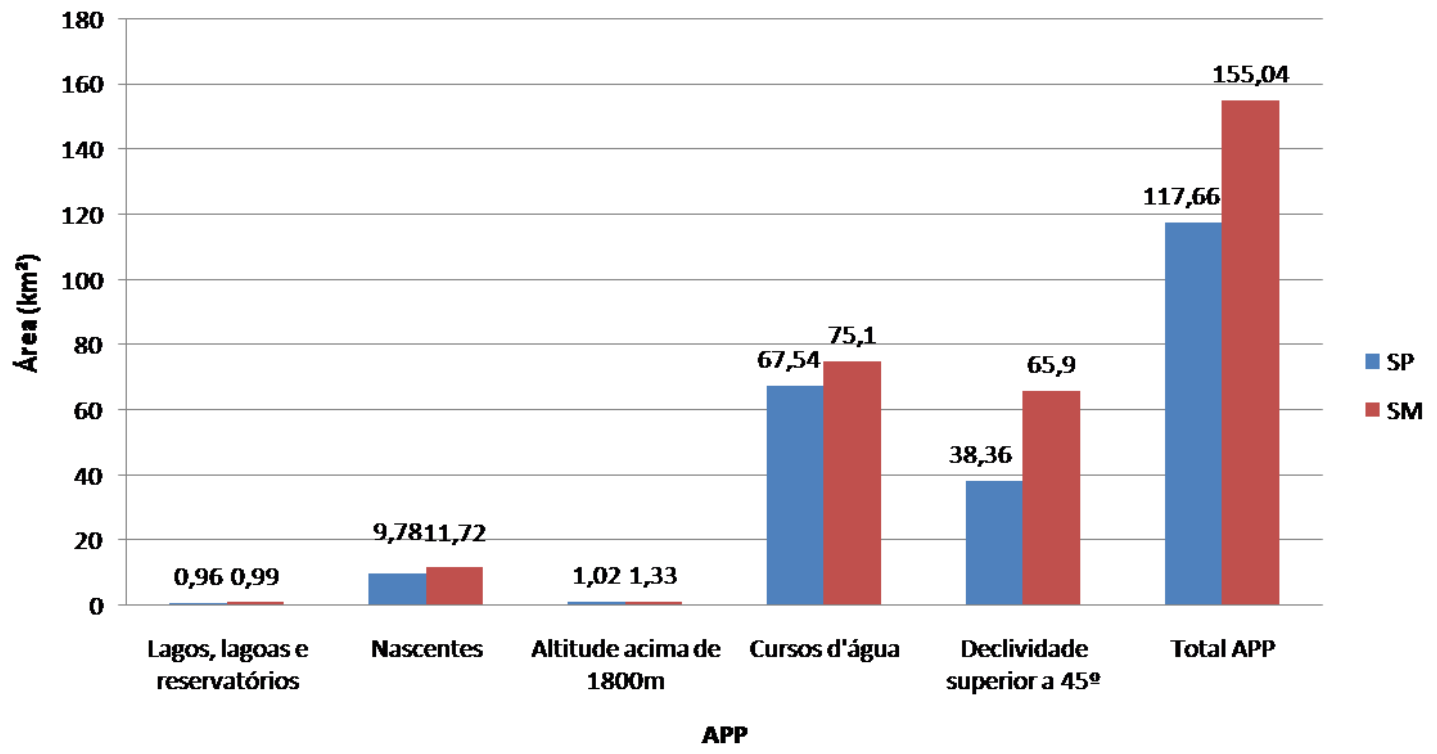

Figura 16. Gráfico da quantificação de APP em superfície planimétrica (SP) e superfície modelada (SM).

Tendo em vista que a APA possui densa rede hidrográfica, a APP com maior área, tanto em superfície planimétrica quanto em superfície modelada é a APP de cursos d'água, seguida da APP de encosta com declividade superior à $45^{\circ}$, já que a APA Petrópolis esta situada em uma região montanhosa, caracterizada por um domínio geomorfológico serrano com encostas muito declivosas. Entretanto, mesmo situada em uma região serrana, a APA não apresenta muitas áreas com altitudes superiores a 1.800 metros, fato este que reflete em uma inexpressiva quantificação de área das APP que são delimitadas por esta característica.

Seguindo o que fora definido na metodologia, as APP de cursos d'água estão diretamente associadas às APP de nascentes, assim, como a APA Petrópolis possui uma rede hidrográfica bastante densa, há também muitas nascentes. Estas nascentes na maioria das vezes se localizam em áreas de encostas declivosas, o que explica o incremento de área em superfície modelada em 1,94 km², o que em termos relativos é bastante expressivo (17,79\%), como é apresentado na figura 17.

A APP menos expressiva na APA é a de lagos, lagoas e reservatórios. Essas APP encontram-se, geralmente, em áreas de baixa declividade, o que explica o baixo incremento de área em superfície modelada $(3,12 \%)$. 


\section{Diferença de área - SP x SM das APP}

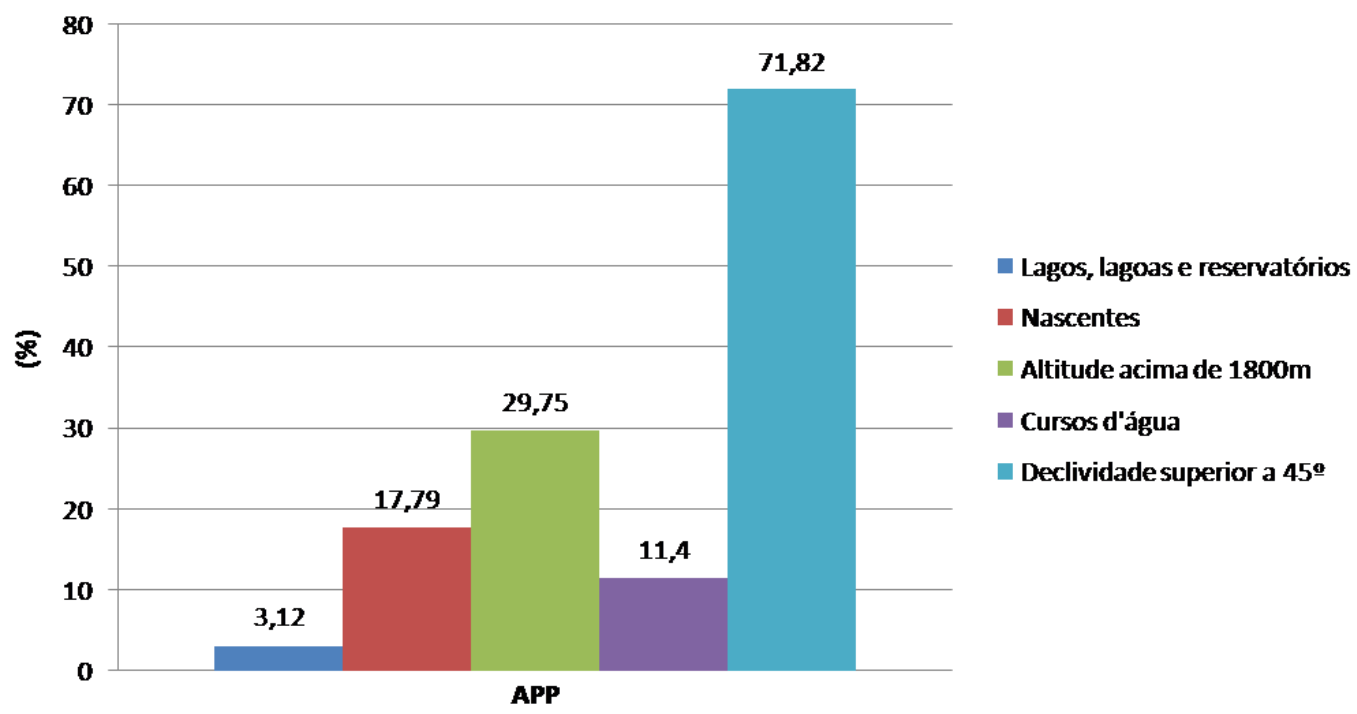

Figura 17. Gráfico da diferença percentual de área de APP em superfície planimétrica (SP) em relação à superfície modelada (SM).

A partir da figura 17 é possível perceber que as APP que mais tiveram incremento de área, quando observada em superfície modelada, são justamente as que estão associadas a áreas de relevo mais acidentado, ou seja, encostas com declividades acentuadas, ou seja, as APP de encostas com declividade superior a $45^{\circ}(71,82 \%)$ e as de altitudes superiores a 1.800 metros $(29,75 \%)$.

A figura 18 demonstra a delimitação de uma APP de nascentes que foi feita em superfície planimétrica e foi projetada em uma superfície 3D (superfície modelada). É possível perceber que a área da delimitação aumenta na superfície modelada, que é o comportamento padrão encontrado em todas as todas as APP encontradas na APA Petrópolis.

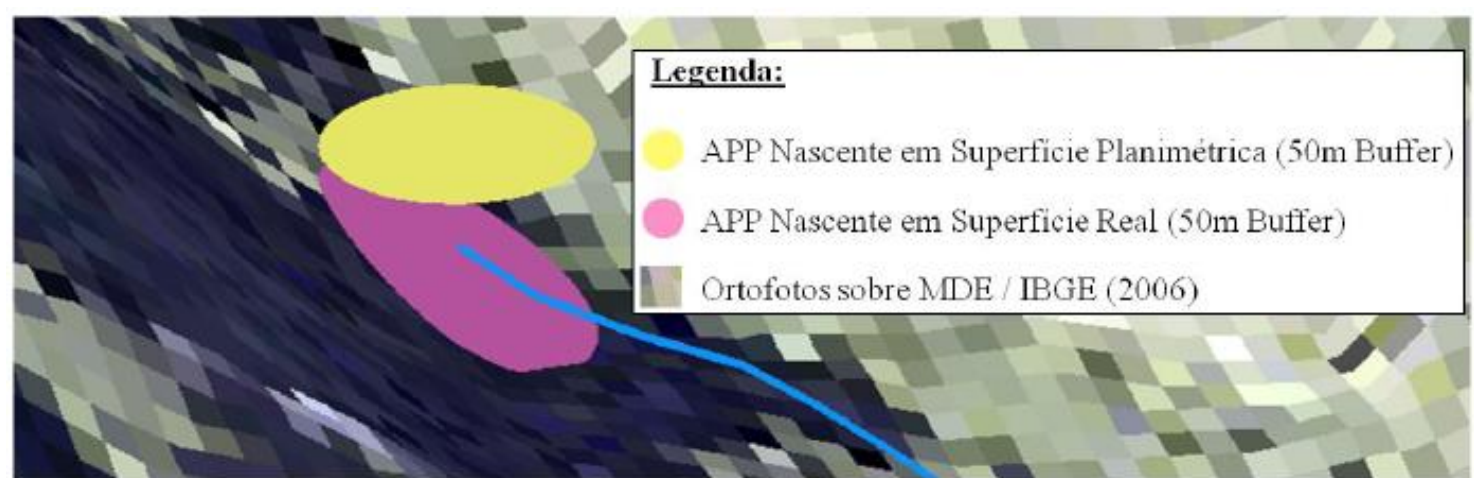

Figura 18. Demonstração de uma APP de nascente delimitada em superfície planimétrica e calculada em superfície planimétrica e superfície modelada. 
Sobre os dados gerados na pesquisa, foram feitas algumas análises preliminares que indicaram inicialmente um nível de preservação baixo de algumas APP, como pode ser visto na figura 19. A ocupação dessas áreas pode comprometer as funções ambientais das APP no ecossistema da região, sendo que algumas dessas funções têm importância direta no bem-estar humano.

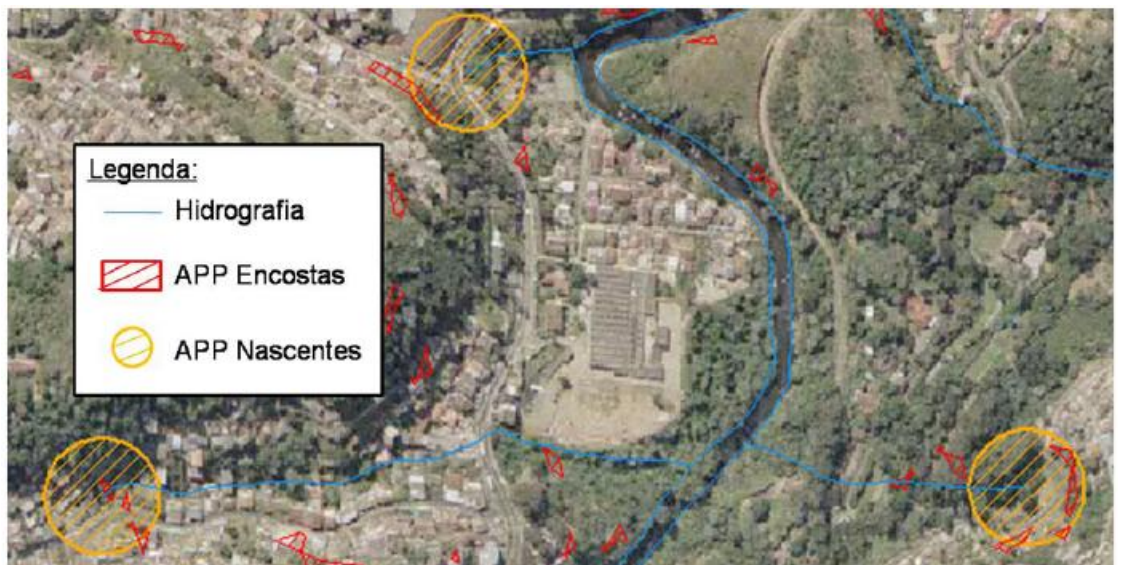

Figura 19. Demonstração do estado de conservação de algumas APP de nascentes e encostas tendo como base as ortofotos do IBGE (2006).

\section{CONCLUSÕES}

O mapeamento em superfície planimétrica das APP e a quantificação dessas áreas em superfície modelada na APA Petrópolis foram concluídos com êxito, porém há ainda a necessidade de mapear essas APP em superfície modelada para que se possa fazer uma melhor avaliação do nível de preservação, levando em consideração a rugosidade do terreno. Claro que isso deve ser bem avaliado de acordo com o que é definido pela legislação, pois dá margem a diferentes delimitações, como sugere Coura (2012).

Existe também a necessidade de ser feito um mapa de vegetação, para que se possa avaliar o nível de preservação e degradação, quantificação de APP em área vegetada e não vegetada, dentre outras análises. Caso os cálculos de área em superfície modelada das APP localizadas em áreas declivosas que foram realizados neste trabalho fossem levados em consideração nas propriedades rurais de dentro da APA Petrópolis, os resultados de área das Reservas Legais seriam diferentes. Assim, entender melhor 
o uso da superfície modelada deve ser encarado pelos agentes tomadores de decisão, para evitar distorções que por ventura possam ocorrer.

Além disso, algumas análises em superfície modelada também podem fazer diferença nos benefícios dados a municípios, já que, de acordo com o Decreto n. ${ }^{\circ} 41.844$, de 4 de maio de 2009 , que estabelece definições técnicas para que seja avaliado o percentual de benefícios financeiros cedido a cada município por conta do ICMS Ecológico. Sendo assim, tanto a parcela da área protegida, quanto o seu nível de conservação, são fatores de avaliação para a distribuição deste imposto aos municípios. Vale ressaltar que, essa diferença de área de superfície planimétrica e modelada é menor em municípios situados em unidades geomorfológicas menos declivosas em contraposição aos municípios que compõem a APA Petrópolis, o que sugere que os municípios com condições semelhantes aos encontrados na APA são prejudicados em função da não consideração de observações em superfície modelada. Desta forma, os municípios que estão contidos na APA Petrópolis poderiam ganhar uma parcela maior desse benefício, pois há um acréscimo de área da APA de 16,52\%.

É válido destacar que as diferenças de áreas das APP nas duas observações aumentam conforme a localização geográfica destas. Ou seja, quanto maior for a predominância de área em regiões declivosas, maiores serão as diferenças de área.

Os resultados desse trabalho podem ser usados por órgãos responsáveis pela gestão e fiscalização de áreas protegidas, além de servirem como instrumento para tomada de decisão para projetos de recuperação de ecossistemas, bem como auxiliar na mediação dos diferentes conflitos ocasionados pelo uso dessas áreas.

\section{REFERÊNCIAS}

Brasil. Manual Técnico de Convenções Cartográficas (1ª parte) - T 34 - 700. Brasília: Ministério da Defesa - Exército Brasileiro, 1998. 108p.

Brasil. Resolução CONAMA n⿳ 303, de 20 de março de 2002. Brasília, 2002. Disponível em:

http://www.mma.gov.br/port/conama/res/res02/res30302.html. Acesso em 12 set. 2010. 
Brasil. Lei n⿳⺈ 12.651, de 25 de maio de 2012. Institui o Novo Código Florestal. Diário Oficial da União, Brasília, DF (2012). Disponível em: <http://www.planalto.gov.br/ccivil_03/_ato2011-2014/2012/lei/l12651.htm>, acessado em maio de 2014.

Brasil. Resolução CONAMA n⿳0 303, de 20 de março de 2002. Dispõe sobre parâmetros, definições e limites de Áreas de Preservação Permanente. Disponível em: <http://www.mma.gov.br/port/conama/res/res02/res30302.html>, acessado em maio de 2014.

COURA, P. H. F. Avaliação das Áreas de Preservação Permanente em Superfície Real na Área de Proteção Ambiental de Petrópolis, Rio de Janeiro. 125f . Dissertação (Mestrado em Geografia) - Programa de Pós-Graduação em Geografia, Instituto de Geociências, Universidade Federal do Rio de Janeiro, 2012.

ESTRUtuRAR. 2005. Programa de Monitoramento da Mata Atlântica da APA Petrópolis: Mapeamento de Vegetação e Uso do Solo. Setembro de 2005.

FELGUEIRAS, C. A. 1997. Apostila do Curso de Modelagem Digital de Terreno e Aplicações. São José dos Campos, INPE, 48 p.

FELGUEIRAS, C. A.; CÂMARA, G. 1999. Modelagem Numérica de Terreno. In: CÂMARA, G.; DAVIS, C.; MONTEIRO, A.M.V. (org.) Introdução à ciência da geoinformação. São José dos Campos: INPE, 1999. Cap. 7. Disponível em: http://www.dpi.ipne.br/livros.php. Acesso em: 28 de Novembro de 2010.

FERNANDES, M.C. Desenvolvimento de Rotina de Obtenção de Observações em Superfície Real: Uma Aplicação em Análises Geoecológicas. 263 f. Tese (Doutorado em Geografia) - Programa de Pós-Graduação em Geografia, Instituto de Geociências, Universidade Federal do Rio de Janeiro, 2004.

FERNANDES, M.C.; AVELAR, A. S.; MENEZES, P. M. L. de; COELHO NETTO, A. L. Comparação do uso de superfície real e planimétrica para análises do índice de eficiência de drenagem: um estudo de caso no Maciço da Tijuca - RJ. Revista Brasileira de Geomorfologia., v.13, p.29 - 37, 2012.

FERNANDES, M.C.; MENEZES, P. M. L. de. Avaliação de métodos de geração de MDE para a obtenção de observações em superfície real: um estudo de caso no maciço da Tijuca - RJ. Revista Brasileira de Cartografia, v. 2, n. 57, p. 154 - 161, 2005.

Instituto Brasileiro de Geografia e Estatística, IBGE. Ortofotos Projeto Rio de Janeiro 1:25.000. 2006. Disponível em: <ftp://geoftp.ibge.gov.br/mapas/ortofoto/Projeto_RJ25/TIF/. Acesso em: 27.set. 2010>.

Instituto Brasileiro do Meio Ambiente e dos Recursos Naturais Renováveis (IBAMA). Plano de Manejo da Área de Proteção Ambiental da Região Serrana de Petrópolis. Brasília, IBAMA, 2007. 489p. p.1-28.

MENEZES, P. M. L. de; FERNANDES, M.C. 2013. Roteiro de Cartografia. v.1. São Paulo: Oficina de Textos, 2013. $288 p$. 
MICELI, B. S. Avaliação de Métricas da Paisagem baseadas em Observações em Superfície Real para a Análise de

Fragmentação Florestal. 130f. Dissertação (Mestrado em Geografia) - Programa de Pós-Graduação em Geografia, Instituto de Geociências, Universidade Federal do Rio de Janeiro, 2011.

MICELI, B. S.; FERNANDES, M.C.; ESTRADA, A. F. D. Análise temporal da cobertura e uso da terra através de observações em superfície modelada na APA Petrópolis, Rio de Janeiro. Geo UERJ, Rio de Janeiro, n. 26, 2015, p. 211225.

TOUTIN, T. 2006. Comparison of 3D physical and empirical models for generating DSMs from stereo HR images. Photogrammetric Engineering \& Remote Sensing, Bethesda, v.72, n.5, p.597-604. 